\title{
Occurrence of Acanthosis Nigricans, A Benign Condition or Associated with Systemic Disease. A Case-Control Study
}

\author{
Acharya $\mathbf{R}^{1}$, Rijal $\mathbf{A}^{2}$ \\ ${ }^{1}$ Lecturer, Patan Academy of Health Sciences, Lalitpur, Nepal, ${ }^{2}$ Professor, Department of Dermatology \& Venereology, \\ B. P. Koirala Institute of Health Sciences, Dharan, Nepal.
}

\begin{abstract}
Background: Acanthosis nigricans (AN), a common cutaneous finding, characterized by hyperpigmentation and velvety hyperplasia of the epidermis affecting flexures. Its exact prevalence varies according to age, race, degree of obesity and endocrinopathy.

Objectives: Though previous studies have identified AN as marker of hyperinsulinemia and its common association with obesity, this study was done to see if AN occurs as benign condition or has any underlying disease and also to identify the possible risk factors associated with it.

Material and methods: Clinically diagnosed cases of $\mathrm{AN}(n=55)$ were included with equal number of healthy control. Height, weight, abdominal circumference, body mass index (BMI), level of Blood Sugar and Lipids were measured. Comorbidities were defined as hypertension: Blood pressure $\geq 140 / 90 \mathrm{mmHg}$; Diabetes mellitus: Fasting Blood sugar (FBS) $>125 \mathrm{mg} / \mathrm{dl}$, Post prandial $>160 \mathrm{mg} / \mathrm{dl}$, Obesity grading as per WHO criteria and Metabolic Syndrome: ATP III criteria. Data were assessed using univariate analysis with crude odds ratio and $95 \%$ confidence intervals. Variables with $p$-value $\leq 0.05$ were tested in multivariate model.

Results: Of 55 cases of AN, $94.5 \%$ had one or more underlying disease. Obesity (89.09\%) was the most common associated condition followed by dyslipidemia (87.2\%), metabolic syndrome (56\%), hypertension (38.18\%), diabetes $(18.8 \%)$ and hypothyroidism (14.54\%). There was a strong association of AN with increased waist circumferences (OR 7.93), BMI (OR 6.8), metabolic syndrome (OR 6.79), family history (OR 4.6) and FBS (OR 3.98). High densitiy lipid (HDL) was found to have protective role (OR 0.36) in AN.

Conclusion: Findings strongly support that patients with AN are at higher risk for having metabolic syndrome with all components than those without AN.
\end{abstract}

Key words: Acanthosis nigricans, Hyperinsulinemia, Obesity

\section{Introduction}

A canthosis nigricans (AN), a common cutaneous finding, is characterized by hyperpigmentation and velvety hyperplasia of the epidermis. In general, it affects flexural areas including the neck, axilla, antecubital and the popliteal fossa. On occasion, the eruption may become almost generalized. But the frequency of the $A N$ is probably underestimated because of the usual asymptomatic character.

The exact prevalence of $\mathrm{AN}$ in unselected population varies from 7 to $74 \%$, according to age, race, degree

\section{Address for correspondence}

Dr. Riti Acharya

Department of Dermatology \& Venereology,

Patan Academy Of Health Sciences (PAHS),

Mobile no: +977- 9849786566.

E-mail: riti_acharya@hotmail.com of obesity and concomitant endocrinopathy. ${ }^{1}$ It is most prevalent among Native Americans, Hispanics, African Americans, and Asian Americans/Pacific Islanders. It is recognized more frequently in darker-skinned obese individuals.

Acanthosis nigricans can be classified as benign or malignant. The benign form $(80 \%)$ is relatively common, contrary to the malignant form, which is rare. $^{2}$ Benign AN often occurs in individuals exhibiting insulin resistance like diabetes mellitus, obesity, and polycystic ovarian syndrome.

It is the most common dermatological manifestation of obesity correlating positively with its severity. The genetic benign form of $A N$ is rare. It seems to be inherited as an autosomal dominance with variable penetrance. $^{3}$ Malignant AN can occur as a rare paraneoplastic syndrome with approximately 1,000 
reported worldwide cases. It is most often seen in adults with an underlying diagnosis of gastrointestinal adenocarcinoma. ${ }^{4}$ Certain medications, such as human growth hormone, oral contraceptives and large doses of niacin, can contribute to this condition.

AN can be classified into 8 variants, including the benign, obesity-associated, syndromic, malignant, acral, unilateral, medication-induced and mixed-type AN. ${ }^{5}$

In 2000, the American Diabetes Association established AN as a formal risk factor for development of Type II Diabetes Mellitus.

Since Acanthosis nigricans is diagnosed clinically, the easy detectability increases its potential to play a bigger role in detecting people at risk. The diagnosis of many systemic disease associated with AN involves a battery of investigations that poses a challenge to doctors working in poor countries. Early screening for AN would provide a relatively simple, inexpensive, and noninvasive tool to detect individuals prone to develop type 2 diabetes as well as other diseases associated with hyperinsulinemia.

Though previous studies have identified AN as marker of hyperinsulinemia and its common association with obesity we are doing this study to see if acanthosis nigricans occurs in a healthy individual or it always has some underlying cause associated and also to study its possible risk factors.

\section{Material and methods}

Fifty-five clinically diagnosed cases of acanthosis nigricans attending dermatology OPD of BPKIHS, Dharan, Nepal over the period of one year were enrolled. Equal number of healthy control were taken from the general population. Sample size was collected using Statcal Epi Info Version 3.1 taking obesity as primary exposure of interest presuming $4 \%$ of general population develop AN compare to $22 \%$ of obese. With Odds ratio of 6.76 for each case 1 healthy control was selected. Sample of 55 cases and control allowed to detect significant association.

Demographic details like age, sex, level of education, family history, duration of disease, associated symptoms were recorded. Medical history to rule out associated systemic disease or use of any drugs and thorough cutaneous examination was done regarding the type of lesions, sites involved. Height, weight, BMI, abdominal circumference, blood sugar and lipid level was obtained for every participant.
Co-morbidities were defined as hypertension: Blood pressure $\geq 140 / 90 \mathrm{~mm} \mathrm{Hg}$; Diabetes mellitus: Fasting Blood sugar (FBS) $>125 \mathrm{mg} / \mathrm{dl}$, Post prandial $>160 \mathrm{mg} /$ $\mathrm{dl}$, Obesity grading as per WHO criteria and Metabolic Syndrome: diagnosed if there was presence of 3 or more criteria of National Cholesterol Education Program (NCEP), Adult Treatment Panel III (ATP III) and International Diabetes Foundation (IDF) for the metabolic syndrome.

Statistical analysis was conducted using EPI info software package version 7.1.1.0 (Centre for Disease Control and Prevention Atlanta, Georgia US). Data were assessed using univariate analysis with crude odds ratio and $95 \%$ confidence intervals. Variables with $p$-value $\leq 0.05$ were tested in multivariate model.

Ethical clearance was received from Institutional Ethical Review Board (IERB), B. P Koirala Institute of Health Science, Dharan, Nepal.

\section{Results}

Total of 110 participants were included in the analysis. Demographic characteristic of the study population is depicted in the table I. Most of the cases had lesion between 1-5ys.. Eleven (20\%) cases did not know that they had pigmentation. Fifty-two (94.55\%) cases developed acanthosis nigricans without any precipitating factor. Majority 35 (63.63\%) of cases had AN involving $2-5 \%$ of BSA.

Achrocordons was the most common associated skin disease seen in 19 (34.54\%) cases. It was mainly distributed over the neck and axilla together with AN. Psoriasis vulgaris was seen in $6(10.9 \%)$, atopic dermatitis in 4(7.27\%), acne vulgaris in 7 (12.72\%) while $12(21.81 \%)$ had other various skin conditions like striae, tinea corporis, polymorphic light eruption, erythema $a b$ igne etc. and $7(12.72 \%)$ had no any other skin diseases except acanthosis nigricans. Table II depicts the characteristics of AN in study population.

Many of the cases were on medication for at least 6 months. Seven (12.72\%) of them were taking antihypertensives namely amlodipine, ACE inhibitors, thiazides and losartan.

Table III depicts the clinical and laboratory parameters of study population.

Of 55 cases of $A N, 94.5 \%$ had one or more underlying disease. Obesity (89.09\%) was the most common associated condition followed by dyslipidemia (87.2\%), 
metabolic syndrome (56\%), hypertension (38.18\%), diabetes (18.8\%) and hypothyroidism (14.54\%).

Univariate analysis showed a high association of increased BMI (OR 12.25), increased waist circumference (OR 7.8), metabolic syndrome (OR 7.58) with AN. Similarly positive family history, use of many known and unknown drugs, raised blood pressure level ( both systolic and diastolic), elevated level of total cholesterol and fasting blood sugar level were associated with $\mathrm{AN}$ and were statistically significant ( $p$ value $<0.01$ )

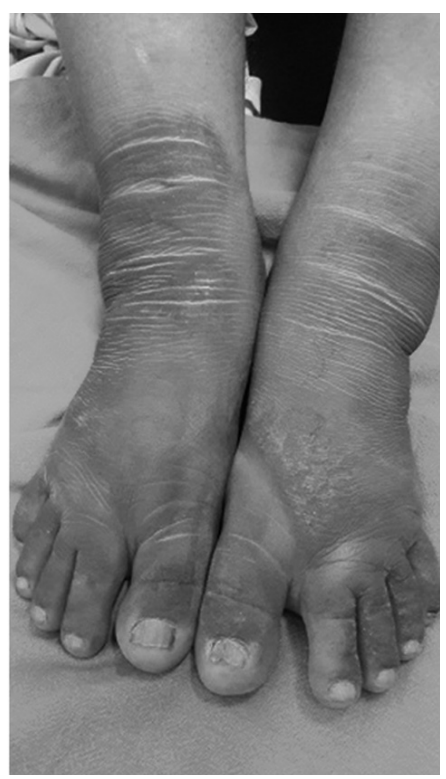

Several other factors like male sex, age above 40 years, alcohol and smoking habit, total cholesterol level, triglyceride level were associated with AN with Odds ratio $>1$ in univariate analysis, however they were not statistically significant.

However multivariate analysis showed strong association of AN with increased waist circumferences (OR 7.93), BMI (OR 6.8), metabolic syndrome (OR 6.79), family history (OR 4.6) and FBS (OR 3.98). HDL was found to have protective role (OR 0.36) in AN (Table IV).

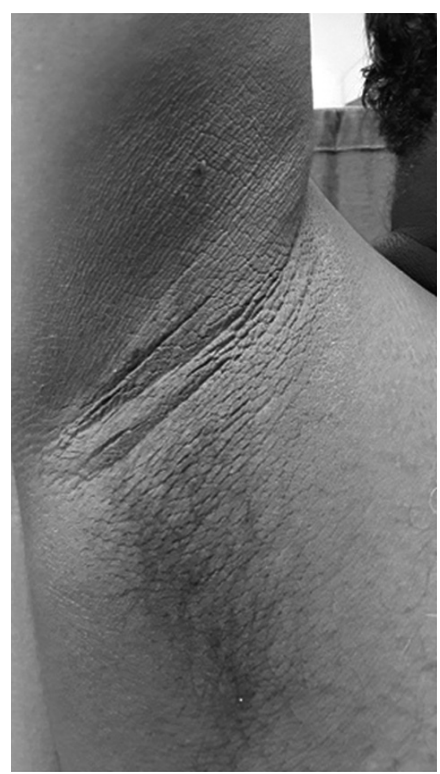

Figure 1: Well developed acanthosis nigricans on dorsum of foot and axilla of a same patient

Table 1: Showing demographic characteristics of study population

\begin{tabular}{|c|c|c|c|}
\hline \multirow{2}{*}{\multicolumn{2}{|c|}{$\begin{array}{l}\text { Characteristics } \\
\text { Factors }\end{array}$}} & \multicolumn{2}{|c|}{ Study population } \\
\hline & & \multirow{2}{*}{$\begin{array}{c}\text { Case (55) } \\
\text { n (\%) } \\
31.8 \pm 10.9 \\
\end{array}$} & \multirow{2}{*}{$\begin{array}{c}\text { Control(55) } \\
\text { n (\%) } \\
30 \pm 8.7\end{array}$} \\
\hline Age in years \pm S.D & & & \\
\hline \multirow{2}{*}{ Gender [n (\%)] } & Male & $34(61.82)$ & $39(70.91)$ \\
\hline & Female & $21(38.18)$ & $16(29.09)$ \\
\hline \multirow{3}{*}{ Literacy [n (\%)] } & Illiterate & $6(10.91)$ & $3(5.45)$ \\
\hline & Intermediate and above & $30(54.55)$ & $13(23.64)$ \\
\hline & Not completed high school & $19(34.55)$ & $39(70.91)$ \\
\hline \multirow{5}{*}{ Occupation [n (\%)] } & Student & $13(23.64)$ & $20(36.36)$ \\
\hline & Housewife & $17(30.90)$ & $10(18.18)$ \\
\hline & Businessman & $8(14.55)$ & $7(12.73 \%)$ \\
\hline & Service holder & $10(18.18)$ & $11(20 \%)$ \\
\hline & Others & $7(12.73)$ & $7(12.2)$ \\
\hline \multirow{2}{*}{ Smoking Habits } & Yes & $17(30.91)$ & $13(23.64)$ \\
\hline & No & $38(69.09)$ & $44(76.36)$ \\
\hline \multirow{2}{*}{ Alcohol habits } & Yes & $16(29.09)$ & $1425.45)$ \\
\hline & No & $39(70.91)$ & $41(74.54)$ \\
\hline
\end{tabular}


Acharya $R$ et al.

Table 2: Showing the characteristics of acanthosis nigricans in cases

\begin{tabular}{|c|c|c|c|c|}
\hline \multicolumn{4}{|l|}{ Characteristics } & Cases $(\mathrm{N}=55)$ \\
\hline \multirow{4}{*}{$\begin{array}{l}\text { Duration of lesion } \\
\text { [n (\%)] }\end{array}$} & \multicolumn{3}{|c|}{ Unknown } & $11(20 \%)$ \\
\hline & \multirow{3}{*}{ Known } & \multirow{3}{*}{$44(80 \%)$} & $0-1 y r$ & 17 (30.9\%) \\
\hline & & & $1 y r-5 y r s$ & $24(43.64 \%)$ \\
\hline & & & $>5 y r s$ & 3 (5.45\%) \\
\hline \multirow{3}{*}{$\begin{array}{l}\text { Precipitating factors } \\
\text { [n (\%)] }\end{array}$} & \multicolumn{3}{|c|}{ Absent } & $52(94.55 \%)$ \\
\hline & \multirow{2}{*}{ Present } & \multirow{2}{*}{$3(5.45 \%)$} & Friction & $2(3.64 \%)$ \\
\hline & & & Drugs & $1(1.82 \%)$ \\
\hline \multirow{3}{*}{ BSA \% [n (\%)] } & \multicolumn{3}{|c|}{$2-5 \%$} & $35(63.6 \%)$ \\
\hline & \multicolumn{3}{|c|}{$5-8 \%$} & $12(21.8 \%)$ \\
\hline & \multicolumn{3}{|c|}{$>8 \%$} & $8(14.5 \%)$ \\
\hline \multirow{7}{*}{ Sites involved [n (\%)] } & \multicolumn{3}{|c|}{ Neck } & $51(91.72 \%)$ \\
\hline & \multicolumn{3}{|c|}{ Axilla } & 35 (63.63\%) \\
\hline & \multicolumn{3}{|c|}{ Groin } & 30 (54.54\%) \\
\hline & \multicolumn{3}{|c|}{ Extremities } & $9(16.36 \%)$ \\
\hline & \multicolumn{3}{|c|}{ Face } & $5(9.09 \%)$ \\
\hline & \multicolumn{3}{|c|}{ Umbilicus } & $2(3.63 \%)$ \\
\hline & \multicolumn{3}{|c|}{ Mucosa } & $1(1.81 \%)$ \\
\hline \multirow{3}{*}{ Types [n (\%)] } & \multicolumn{3}{|c|}{ Obesity induced } & 49 (89.08\%) \\
\hline & \multicolumn{3}{|c|}{ Mixed } & $4(7.27 \%)$ \\
\hline & \multicolumn{3}{|c|}{ Acral } & $2(3.63 \%)$ \\
\hline \multirow{6}{*}{$\begin{array}{l}\text { Associated skin } \\
\text { diseases } \\
{[n(\%)]}\end{array}$} & \multicolumn{3}{|c|}{ None } & $7(12.72 \%)$ \\
\hline & \multirow{5}{*}{ Present } & \multirow{5}{*}{$48(87.28 \%)$} & Achrocordons & 19 (34.54\%) \\
\hline & & & Acne vulgaris & $7(12.72 \%)$ \\
\hline & & & Atopic dermatitis & $4(7.27 \%)$ \\
\hline & & & Psoriasis & $6(10.9 \%)$ \\
\hline & & & Others & $12(21.81 \%)$ \\
\hline
\end{tabular}

Table 3: Showing the clinical and laboratory parameters of study population

\begin{tabular}{|c|c|c|c|}
\hline \multicolumn{2}{|l|}{ Factors } & \multirow{2}{*}{$\begin{array}{c}\text { Cases (55) = N (\%) } \\
19(34.55)\end{array}$} & \multirow{2}{*}{$\begin{array}{c}\text { Control (55) =N (\%) } \\
28(50.91)\end{array}$} \\
\hline \multirow{3}{*}{$\begin{array}{l}\text { Systolic BP } \\
(\mathrm{mmHg})\end{array}$} & $<120$ & & \\
\hline & $120-140$ & $34(61.82)$ & $26(47.27)$ \\
\hline & $>140$ & $2(3.64)$ & $1(1.82)$ \\
\hline \multirow{3}{*}{$\begin{array}{l}\text { Diastolic BP } \\
\text { (mmHg) }\end{array}$} & $<80$ & 16 (29.09) & 21 (38.18) \\
\hline & $80-90$ & $36(65.45)$ & $32(58.18)$ \\
\hline & $>90$ & $3(5.45)$ & $2(3.64)$ \\
\hline \multirow{3}{*}{ Fasting blood sugar (mg/dl) } & $<100$ & $33(60)$ & $43(78.18)$ \\
\hline & $100-125$ & $2(3.63)$ & $5(9.09)$ \\
\hline & $>125$ & $20(36.36)$ & $7(12.72)$ \\
\hline \multirow{3}{*}{$\begin{array}{l}\text { Total cholesterol } \\
\text { (mg/dl) }\end{array}$} & $\leq 200$ & 35 (63.63) & $46(83.64)$ \\
\hline & $200-239$ & $14(25.45)$ & $6(10.91)$ \\
\hline & 240 & $6(10.91)$ & $3(5.45)$ \\
\hline \multirow{3}{*}{$\begin{array}{l}\text { Triglyceride } \\
\text { (mg/dl) }\end{array}$} & $<150$ & 30 (54.55) & 35 (63.64) \\
\hline & $150-199$ & $12(21.82)$ & $10(18.18)$ \\
\hline & $200-500$ & $13(23.64)$ & $10(18.18)$ \\
\hline
\end{tabular}




\begin{tabular}{|l|c|c|c|}
\hline \multirow{3}{*}{\begin{tabular}{l}
\multirow{3}{*}{$(\mathrm{mg} / \mathrm{dl})$} \\
\cline { 2 - 3 }
\end{tabular}} & $<100$ & $17(30.91 \%)$ & $25(45.45)$ \\
\cline { 2 - 4 } & $100-129$ & $16(29.09 \%)$ & $15(27.27)$ \\
\cline { 2 - 4 } & $130-159$ & $19(34.55)$ & $5(18.18)$ \\
\hline \multirow{3}{*}{$\begin{array}{l}\mathrm{HDL} \\
\text { (mg/dl) }\end{array}$} & $160-189$ & $3(5.45)$ & $24(43.64)$ \\
\cline { 2 - 4 } & $<40$ & $34(61.61)$ & $59(50.91)$ \\
\cline { 2 - 4 } & $40-60$ & $19(34.55)$ & $3(5.45)$ \\
\hline
\end{tabular}

Table 4: Clinical and laboratory parameters associated with acanthosis nigricans in univariate and multivariate analysis

\begin{tabular}{|c|c|c|c|c|c|c|c|c|}
\hline \multirow[b]{2}{*}{ Variable } & \multicolumn{2}{|c|}{ Disease exposed } & \multirow{2}{*}{$\begin{array}{l}\text { Crude } \\
\text { odds } \\
\text { ratio }\end{array}$} & \multirow{2}{*}{$\begin{array}{c}\text { Confidence } \\
\text { interval }\end{array}$} & \multirow[b]{2}{*}{$P$ value } & \multirow{2}{*}{$\begin{array}{l}\text { Adjusted } \\
\text { Odds } \\
\text { Ratio }\end{array}$} & \multirow[b]{2}{*}{$95 \% \mathrm{Cl}$} & \multirow[b]{2}{*}{ P-value } \\
\hline & $\begin{array}{c}\text { Cases } \\
\mathrm{N}=55(\%)\end{array}$ & $\begin{array}{l}\text { Control } \\
\mathrm{N}=55(\%)\end{array}$ & & & & & & \\
\hline $\begin{array}{c}\text { BMI (kg/m2) } \\
\geq 25 \\
<25\end{array}$ & $\begin{array}{c}49(89.09) \\
6(10.9) \\
\end{array}$ & $\begin{array}{l}22(40) \\
33(60)\end{array}$ & $\begin{array}{c}12.25 \\
\text { ref }\end{array}$ & $4.48-33.46$ & $\leq 0.001$ & 6.82 & $2.23-24.84$ & 0.007 \\
\hline $\begin{array}{c}\text { Family history } \\
\text { Yes } \\
\text { No }\end{array}$ & $\begin{array}{l}34(61.88) \\
21(38.18) \\
\end{array}$ & $\begin{array}{l}12(21.81) \\
43(78.18)\end{array}$ & $\begin{array}{c}5.80 \\
\text { ref }\end{array}$ & $2.50-13.43$ & $\leq 0.001$ & 4.60 & $1.72-12.30$ & 0.002 \\
\hline $\begin{array}{c}\text { Past drug history } \\
\text { Yes } \\
\text { No } \\
\end{array}$ & $\begin{array}{l}23(41.8) \\
32(58.1)\end{array}$ & $\begin{array}{l}7(12.72) \\
48(87.2)\end{array}$ & $\begin{array}{c}4.92 \\
\text { ref }\end{array}$ & $1.89-12.8$ & $\leq 0.001$ & $\because$ & - & - \\
\hline $\begin{array}{l}\text { Waist }(\mathrm{F} / \mathrm{M})(\mathbf{c m s}) \\
\quad \leq 80 / \leq 90 \\
>80 \text { and }>90\end{array}$ & $\begin{array}{c}15(27.2) \\
40(72.72)\end{array}$ & $\begin{array}{l}41(74.54) \\
14(25.45) \\
\end{array}$ & $\begin{array}{c}7.80 \\
\text { ref }\end{array}$ & $3.34-18.24$ & $\leq 0.001$ & 7.93 & $3.18-19.78$ & $\leq 0.001$ \\
\hline $\begin{array}{c}\text { Diastolic BP } \\
\geq 90 \mathrm{mmHg} \\
<90 \mathrm{mmHg}\end{array}$ & $\begin{array}{c}12(21.8) \\
43(78.18)\end{array}$ & $\begin{array}{c}3(5.45) \\
52(94.5)\end{array}$ & $\begin{array}{c}4.83 \\
\text { ref }\end{array}$ & $1.28-18.25$ & 0.01 & - & - & - \\
\hline $\begin{array}{c}\text { Fasting Blood Sugar } \\
>125 \mathrm{mg} / \mathrm{dl} \\
\leq 125 \mathrm{mg} / \mathrm{dl}\end{array}$ & $\begin{array}{l}20(36.36) \\
35(63.64)\end{array}$ & $\begin{array}{c}7(12.73) \\
48(87.27) \\
\end{array}$ & $\begin{array}{c}3.91 \\
\text { ref }\end{array}$ & $1.49-10.28$ & 0.003 & 3.98 & $1.31-12.17$ & 0.015 \\
\hline $\begin{array}{l}\text { Cholesterol } \\
>200 \mathrm{mg} / \mathrm{dl} \\
\leq 200 \mathrm{mg} / \mathrm{dl}\end{array}$ & $\begin{array}{l}20(36.36) \\
35(63.63)\end{array}$ & $\begin{array}{c}9(16.3) \\
46(83.63)\end{array}$ & $\begin{array}{c}2.92 \\
\text { ref }\end{array}$ & $1.18-7.19$ & 0.01 & - & - & - \\
\hline $\begin{array}{l}\text { Low Density } \\
\text { Lipoprotein } \\
\leq 160 \mathrm{mg} / \mathrm{dl} \\
>160 \mathrm{mg} / \mathrm{dl}\end{array}$ & $\begin{array}{c}52(94.5) \\
3(5.45)\end{array}$ & $\begin{array}{c}50(90.9) \\
5(9.09)\end{array}$ & $\begin{array}{c}0.64 \\
\text { ref }\end{array}$ & $0.17-2.40$ & 0.50 & - & - & - \\
\hline $\begin{array}{l}\text { High Density } \\
\text { Lipoprotein } \\
\geq 40 \mathrm{mg} / \mathrm{dl} \\
<40 \mathrm{mg} / \mathrm{dl}\end{array}$ & $\begin{array}{l}20(36.36) \\
35(63.63)\end{array}$ & $\begin{array}{l}31(56.36) \\
24(43.63)\end{array}$ & $\begin{array}{c}0.44 \\
\text { ref }\end{array}$ & $0.20-0.95$ & 0.03 & 0.36 & $0.14-0.86$ & 0.023 \\
\hline $\begin{array}{c}\text { Metabolic syndrome } \\
\text { Yes } \\
\text { No }\end{array}$ & $\begin{array}{c}31(56.3) \\
24(43.63)\end{array}$ & $\begin{array}{c}8(14.5) \\
47(85.4)\end{array}$ & $\begin{array}{c}7.58 \\
\text { ref }\end{array}$ & $3.02-19.03$ & $\leq 0.001$ & 6.79 & $2.58-17.91$ & $\leq 0.001$ \\
\hline
\end{tabular}




\section{Discussion}

Acanthosis nigricans (AN) is an important cutaneous finding that may signify internal disease. It rarely occurs in a healthy individual. It is usually diagnosed clinically by inspecting the skin.

The definitive cause of AN has not yet been ascertained. The most common mechanism identified is mediated through insulin resistance (IR). Both the hyperinsulinism and the increase in IGF-1 directly induce epithelial and fibroblastic growth by activating receptors; this mediates epidermal cell proliferation leading to development of AN.

Obesity-associated AN was the most common type of AN. Neck(92.7\%) was the most common site involved followed by axilla (63.3\%) which was similar to study by Puri N. ${ }^{6}$ Easy visibility of AN over exposed area like neck compared to other enclosed areas could be the possible explanation.

Half of the cases had lesions for more than a year while $11(20 \%)$ did not know about the condition at the time of diagnosis. AN being an asymptomatic condition rarely draws the patient's attention towards the skin condition.

Though literature supports no sex predilection for AN, our study showed females at high risk for AN similar to study by Menon. ${ }^{7}$ Tendency to gain weight during pregnancy and after delivery, less manual work compared to male counterparts, increase incidence of endocrine disease like hypothyroidism may contribute in having increase BMI in women and subsequent development of AN.

People into business, service, students and housewives and those who were more literate and in the higher socio-economic status having high incidence of AN. Majority of the illiterate population are into farming and heavy manual work and reside in rural areas of Nepal with poor access to health facilities, this might have caused AN to be uncommon among illiterates and low socio economic status.

Family history positive for HTN, DM, obesity and endocrinopathies have shown four-fold increased risk of AN in the current study. Study done by Stoddart, reported parental history of type 2 diabetes had increased prevalence of $\mathrm{AN}$ and hyperinsulinemia. ${ }^{8}$ Though direct relation with family history of $A N$ is not seen except for various syndromes, studies suggest that family history of Diabetes definitely has some association with AN.
Drugs increased approximately 5 fold risk of AN in our study. About $13 \%$ were on anti hypertensives, of which few were thiazide and beta blockers. These drugs are known to cause insulin resistance in healthy individual and adverse glycemic control in diabetics.

Our study had $34.5 \%$ of cases with achrocordons almost comparable to study done by Puri. ${ }^{6}$ Both the hyperinsulinism and the increase in IGF-1 directly induce epithelial and fibroblastic growth by activating receptors, possibly explaining the prevalence of skin tags and obesity induced AN among cases.

Approximately $11 \%$ cases of AN were associated with psoriasis. As central obesity which causes insulin resistance and $\mathrm{AN}$, it is also associated with abnormal levels of inflammatory markers like tumor necrosis factor $\alpha$ (TNF- $\alpha$ ) and interleukin 6(IL-6), these factors may contribute to the pathogenesis of psoriasis.

About $95 \%$ of the cases had AN with one or more underlying disease, with only $5 \%$ was seen in healthy individuals. This was in contrast to study by Grandhe NP where $65 \%$ diabetics and $40 \%$ healthy people had AN. ${ }^{9}$

Overweight and obesity (89.09\%) was the most common benign condition associated with AN with 8-9 fold increased risk as observed by Puri N. ${ }^{6}$ AN was significantly common in people with metabolic syndrome (56\%). Majority had three out of five components with few cases having four or more components of MS in a single patient. Similar result was seen by Dassanayake in his study where he concluded that presence of AN strongly predicts MS. ${ }^{11}$

Patients with $\mathrm{AN}$ are at risk for all components of metabolic syndrome (MS) such as, obesity, hypertension, elevated triglycerides, low HDL, and impaired glucose tolerance. Dyslipidemia was common among our population. However in our study we found increased level of total cholesterol associated with almost 3 times increased risk for development of AN. Obesity is the major etiology behind almost all metabolic condition for development of insulin resistance (IR) and AN.

Patients with AN are likely to have multiple risk factors for type 2 diabetes among which AN may be an independent risk factor for this disease. Our study showed increased level of fasting blood sugar in cases compared to control with almost 4 fold increased risk for AN and it was statistically significant. This was similar to study done by Hud et al, in which mean fasting blood glucose concentration was higher in patients with $\mathrm{AN}$ than in patients without $\mathrm{AN} .^{10}$ 
The study demonstrates the feasibility of AN screening and type 2 diabetes risk reduction counseling in general population. Second, as the epidemic of obesity and the MS continues to increase, AN screening has the potential of early identification an timely management of underlying condition.

\section{Conclusion}

Findings of the study suggest that majority of patients with AN have multiple underlying diseases. Authors strongly recommend certain physical examination and few basic studies in all patients with AN for early detection of underlying cause.

Acknowledgements: My sincerest gratitude to all my patients, epidemiologist Mr. Surendra Uraw and my department.

\section{References}

1. Barbato MT, Criado PR, da Silv AK, Averbeck E, Guerine MB, Bittencourt de Sá N. Association of acanthosis nigricans and skin tags with insulin resistance. An Bras Dermatol 2012; 87: 97-104. http://dx.doi.org/10.1590/S036505962012000100012

2. Silva JA, Mesquita KC, Igreja AC, Lucas IC, Freitas $A F$, Oliveira SM, et al. Paraneoplastic cutaneous manifestations: Concepts and updates. An Bras Dermatol 2013; 88: 9-22. http://dx.doi. org/10.1590/S0365-05962013000100001

3. Sinha $S$ and Schwartz RA. Juvenile acanthosis nigricans. J Am Acad Dermatol 2007; 57: 502-8. http://dx.doi.org/10.1016/j.jaad.2006.08.016

4. Isaacoff E, Dimitriadi FF, Barrows F, Pawel B, Mattei P, Mostoufi-Moab S. Acanthosis nigricans associated with an adrenocortical tumor in a pediatric patient. Case reports in endocrinology 2013; ID: 174593.

5. Schwartz RA. Acanthosis nigricans. J Am Acad Dermatol 1994; 31: 1-19. http://dx.doi. org/10.1016/S0190-9622(94)70128-8

6. Neerja Puri. A Study of pathogenesis of acanthosis nigricans and its clinical implications. Indian J Dermatol 2011; 56: 678-83. http://dx.doi.org/10.4103/00195154.91828

7. Menon VU, Kumar KV, Gilchrist A, Sundaram KR, Jayakumar RV, Nair $V$ et al. Acanthosis
Nigricans and insulin levels in a south Indian population-(ADEPS paper 2). Obes Res Clin Pract 2008; 2: I-II. http://dx.doi.org/10.1016/j. orcp.2007.12.001

8. Stoddart $\mathrm{ML}$, Blevins $\mathrm{KS}$, Lee $\mathrm{ET}$, Wang W, Blackett PR; Cherokee Diabetes Study. Association of acanthosis nigricans with hyperinsulinemia compared with other selected risk factors for type 2 diabetes in Cherokee Indians: the Cherokee Diabetes Study. Diabetes Care 2002; 25: 1009-14. http:// dx.doi.org/10.2337/diacare.25.6.1009

9. Grandhe NP, Bhansali A, Dogra S, Kumar B. Acanthosis nigricans: relation with type 2 diabetes mellitus, antropometric varables, and body mass in Indians. Post Med J 2005, 81: 541-4. http://dx.doi.org/10.1136/ pgmj.2004.028308

10. Hud JA, Cohen JB, Wagner JM, Cruz PD. Prevalence and significance of acanthosis nigricans in an adult obese population. Arch dermatol 1992; 128: 941-4. http://dx.doi. org/10.1001/archderm.1992.01680170073009

11. Dassanayake AS, Kasturiratne A, Niriella MA, Kalubovila U, Rajindrajith S, de Silva AP et al. Prevalence of acanthosis Nigricans in an urban population in Sri Lanka and its utility to detect metabolic syndrome. BMC Res Notes 2011; 4: 25. http://dx.doi.org/10.1186/1756-0500-4-25 